\title{
The Motivation of Young Chili Farmers in Sandy Land of Special Region of Yogyakarta, Indonesia
}

\author{
Siti Nurlaela ${ }^{1, *}$ \\ ${ }^{1}$ Politeknik Pembangunan Pertanian Yogyakarta-Magelang
}

\begin{abstract}
Senior farmers in Panjatan, Kulonprogo, Yogyakarta, have succeeded in making sandy land a horticultural center. However, this success does not motivate young farmers to continue farming. The declining interest of the agricultural sector of youth occurs because they realize the high risk in agricultural entrepreneurship. This study analyzed young farmers' motivation and roles in horticultural entrepreneurship in the coastal sandy land. A sample of 120 respondents from four farmer groups was taken using simple random sampling. Percentage, mean score, and Spearman's rank correlation at $\mathrm{p} \leq 0.05$ were employed to analyze the data. There was a significant relationship $(\mathrm{p} \leq 0.05)$ between groups' roles as a vehicle for learning and motivation ( $\mathrm{rs}=0.25$ ). The role of groups in collaboration and networking was insignificant. Therefore, to motivate young coastal sandy farmers, it is necessary to optimize groups' role as a vehicle for learning. Thus, the government needs to implement a strategy to encourage young farmers' motivation by strengthening their roles by improving their knowledge of horticulture business, including training, internships, and discussions on technological developments by regularly utilizing young farmer group meetings.
\end{abstract}

\section{Introduction}

Farmers' succession begins through farming by helping their parents. They are accustomed to farming because, since childhood, they see their parents doing activities on the farm. However, after they grow up, many of these young farmers are not involved in farming activities or continue their parents' farming business due to the enormous agricultural entrepreneurship challenges. Young farmers are reluctant to farm on sandy land because it requires more time, skills, and perseverance than farming in rice fields. Sandy fields have a low buffering ability and high evaporation, very low fertility and organic matter, and low water use $[1,2]$. Under these conditions, farmers must water their farms at least once a day to keep it moist.

Initially, the coastal sandy land in Panjatan, Kulonprogo, Yogyakarta, Indonesia, could not be used for farming. The idea to establish a sand farm was initiated by the community leader who had come up with the idea by looking at chili plants growing accidentally on sandy soil. In the early 1980 s, the leader pioneering sand land farming took the initiative to plant chili in the sand field [3]. The first attempt was successful, but the harvest was

\footnotetext{
* Corresponding author: nurlaela77yk@gmail.com
} 
unsatisfactory. After several attempts, he finally succeeded in planting chilies in the sand land with satisfying harvests. The persistence to keep on trying made other farmers see the leader's success and followed his steps to establish a coastal sandy farm. They built influential farmer groups with various activities in the development, including holding an auction market. The sandy area in the Special Region of Yogyakarta is now a buffer for agricultural products, capable of producing commodities such as chili, vegetables, and watermelons. The farmers of the sandy area even become suppliers for markets in Cipinang, Jakarta, and Sumatra.

Despite the success the farmers have achieved, they face challenges. The foremost challenge is price fluctuation, especially during the big harvest. At the beginning of 2019, farmers found prices for their commodities to fall below IDR 5,000/kg, or USD $0.3 / \mathrm{kg}$. They did not even want to harvest the chilies because the predicted income from the harvest did not worth the efforts they had to expend. The volatile price condition has become an exceptional experience for farmers, especially young ones.

Over time, the generation starting coastal sand farms has aged. However, few young people are eager to continue managing their parents' farms. Youth, who should be the next generation of chili farmers on sandy lands, are not ready. Most young people from the area have moved to find other engagements in the city. If allowed to continue, this condition will affect chili's productivity, especially in the Special Region of Yogyakarta, Indonesia. Low income is a significant factor causing a decline in rural youth's interest and motivation to become farmers. The low motivation of farmer children is also expressed by [4] and [5]. The small percentage of village youth interested in agriculture is due to the uncertainty of farming's benefits. As an agricultural entrepreneur, producing chili is full of risk because of environmental conditions, pest attacks, and price fluctuations. Various technical obstacles challenge the farmers in capital constraints, limited land, and price fluctuations.

Horticulture in coastal sand fields has developed with the role of farmer groups. Young farmer groups can be a fundamental instrument in dealing with entrepreneurial problems. Santrock [6] stated that peers could significantly influence one's motivation, especially at a young age. Farmer's groups have relatively the same age, activity and area, as the [7] study results. Through the activities of young farmer groups, the youth can interact and exchange experiences. Their success in socializing will positively impact their development. The importance of groups in farming is also found in $[8,9,10]$.

Young farmers join farmer groups to obtain information about farming, technology, and market access. The farmer group in the coastal sand field is significant because young farmers can meet and discuss business conditions. The business condition is related to access to input to start planting, accessing seeds, and fertilizer subsidized by the government. Meanwhile, for initial farmers such as young coastal sandy field farmers, joining the group will help them succeed in farming.

Motivation can also influence young farmers' success in entrepreneurship, as indicated by [11]. A motivation theory based on Alderfer's needs is used to understand young farmers' motivation in horticultural entrepreneurship. It is considered the easiest way to identify young farmers' motivation to become young farmers, as choices have meaning and purpose[12]. Based on Alderfer's need theory [13, 14], human motivation is influenced by physical needs and existence, relatedness needs, and growth needs. This theory was revised. Maslow's theory, each of which evaluates human needs hierarchically.

This study aims to determine young farmers' characteristics, the horticultural motivation of young farmers in the coastal sand field, the roles of farmer groups in entrepreneurship, and the relationship between young farmers' roles and entrepreneurial motivation. These findings are expected to produce the most appropriate approach. The youth is interested in the agricultural sector, thus reducing regeneration over farmers in the coastal sandy area in Panjatan. 


\section{Methodology}

The research location was in the chili producing area and the coastal sand land of Panjatan District, Kulonprogo Regency, Yogyakarta Special Region, Indonesia, conducted in JanuaryJune 2019. In this study, the respondents' criteria were young farmers who were horticultural entrepreneurs within 18-40 years who joined farmer groups. The population comprised 422 people in four farmer groups, gathered by simple random sampling. The number of samples taken was 120 people.

The research variables included entrepreneurial motivation and the groups' roles. Entrepreneurial motivation consisted of existence, relatedness, and growth, as identified by Alderfer. Motivation variables were measured using a 5-point rating scale of extremely do not want (1), do not want (2), doubtful (3), want (4), and highly want (5). The role of the groups included a vehicle for learning, collaboration, and networking. The groups' roles were measured using a 5-point rating scale of: never (1), rarely (2), sometimes (3), often (4), and always (5). The characteristics of young farmers include gender (1) for men, (0) for women, age, and education level calculated based on years of education as a primary school (6), junior high school (9), high school (12), and college (17). Percentages and average scores were used to analyze young farmers' characteristics, groups' roles, and motivation to farm. The relationship between the roles of groups and motivation was determined using the Spearmanrank correlation at $\mathrm{p} \leq 0.05$.

\section{Results and Discussion}

\subsection{Characteristics of Young Chilli Farmers in Sandy Land}

The characteristics of farmers, including sex, age, and educational level, can affect agricultural entrepreneurship, according to $[15,16]$. Table 1 shows the characteristics of young chili farmers in the sandy land area.

Table 1. Young Farmers' Characteristics

\begin{tabular}{|l|l|}
\hline \multicolumn{1}{|c|}{ Variables } & \\
\hline Sex & Percentage (n=120) \\
\hline Male & 93.33 \\
\hline Female & 6.67 \\
\hline Age (years) & \\
\hline$\leq 20$ & 11 \\
\hline$>21-30$ & 18 \\
\hline$>31-40$ & 69 \\
\hline Mean=34.1 & \\
\hline Level of Education & \\
\hline Primary School & 0.83 \\
\hline Junior High School & 23.33 \\
\hline High School & 69.17 \\
\hline College & 6.67 \\
\hline
\end{tabular}

Source: Primary Data Analysis (2019)

The results in Table 1 indicate that men (93.33\%) have more agricultural activities than women. Farming work requires physical strength. Therefore, male laborers are more essential in farming, especially in sand fields. This result is in line with [4] and [17], stating that agricultural activities, especially production, are mostly carried out by men. Furthermore, most young farmers' education levels were High School/Vocational High School (69.17\%). 
These data follow the Agricultural Census [18], revealing that young farmers have a relatively high education level than older farmers. There is an increase in education level compared to previous research, which is still dominated by Primary and Middle School graduates.

\subsection{The Roles of Young Farmer Groups in Coastal Sandy Land}

Minister of Agriculture Regulation No.67/PERMENTAN/SM.050/12/2016 states that the roles of farmer groups are: (a) learning classes, farmer groups are a place for teaching and learning for their members to improve knowledge and skills in farming; (b) a vehicle for cooperation; a farmer group is a place to strengthen cooperation between fellow farmers in the group and between farmer groups and with other parties; (c) production units, the farmer group plays a role in making decisions in determining the development of profitable production. The process of adopting technology and information can run more effectively through farmer groups as [19]. Furthermore, according to previous research, farmer groups in this study act as a vehicle for learning, cooperation, and networking [3, 20].

Table 2. The Roles of farmer groups

\begin{tabular}{|l|c|}
\hline \multicolumn{1}{|c|}{ Variables } & Mean \\
\hline Learning & 3.69 \\
\hline Cooperation & 3.06 \\
\hline Building a network & 3.18 \\
\hline Mean Total & 3.14 \\
\hline
\end{tabular}

Source: Primary Data (2019)

Table 2 depicts the mean of the role of farmer groups is sometimes (3.04), indicating that young farmers sometimes use groups to support agricultural entrepreneurship. Sequentially, groups' roles in entrepreneurship include learning vehicles (3.69), building networks (3.18), and a vehicle for cooperation (3.14). Groups as a vehicle for learning (3.69) play the highest role in supporting entrepreneurship. Young farmers think that groups can sometimes improve the knowledge and skills of their members. Good learning abilities can increase the adoption of technology and innovation in farming and marketing. These results are in line with [21], stating that young farmer groups function as vehicles for mutual learning, production and marketing cooperation, and building networks. The second role of the groups is to build networks. Efforts to build networks (3.18) have been carried out through group-based auction market activities, building communication with extension agents, NGOs, and educational institutions. The auction market can play a role in dealing with price fluctuations. However, the auction market's development still needs to be enhanced by building a more comprehensive network. Efforts to build networks can increase farmers' bargaining to determine commodity prices described by previous research [11, 22, 23, 24], stating that farmers will get a better bargaining price advantage as a group. However, sales through group-based auction markets running for a long time need innovation and network improvement to continue developing. In cooperation between group members (3.06), farmers have carried out group-based capital provision activities, although the numbers are minimal. The group has not optimized cooperation between members in providing seeds and other agricultural facilities. The group only distributed government programs in the form of fertilizer and subsidies for seeds.

\subsection{Young Farmers' Motivation to Farm in Coastal Sandy Land}

Motivation is the process causing to be energized, directed, and sustained. It is a force in human beings that cause, direct, and organize behavior. Furthermore, [25] suggested that the 
appropriate theory to use is motivation theory based on needs, not hierarchical related to the absence of an intervention program in motivating young farmers. Young farmers' motivation to conduct farming in the coastal sand field can be analyzed using this theory. This theory states that a person's motivation consists of three issues: existence, including physiological and security need, relatedness involving the social needs and interactions with others, including love, and growth covering the motivation to be creative and beneficial to others. This definition is a reflection of self-esteem and self-actualization. Young farmers' motivation in chili farming is demonstrated in Table 3.

Table 3. Young Farmers' Motivation to Chilli Farming in Coastal Sandy Land

\begin{tabular}{|l|l|}
\hline \multicolumn{1}{|c|}{ Variables } & \multicolumn{1}{c|}{ Mean } \\
\hline Existence Motivation & 4.22 \\
\hline Relatedness Motivation & 4.09 \\
\hline Growth Motivation & 3.58 \\
\hline Mean Total & 3.96 \\
\hline Source: Primary Data (2019)
\end{tabular}

Table 3 shows that young farmers' motivation to farm in coastal sandy land is 3.96 on average, belonging to the category of wanting. The highest motivation is the existence of motivation (4.22). This result suggests that young farmers are motivated to carry out business because they can meet physical and security needs. Being a farmer is the last and most beneficial choice for young people who do not migrate. With a high school degree, it is hardly possible to look for other jobs in a sandy land environment except to be a farmer.

The value of relatedness motivation (4.09) is relatively high. Thus, young farmers are motivated to become farmers because of their desire to work with other young farmers. This effort is carried out by supplying seeds, fertilizer assistance, borrowing capital, and agricultural machinery, providing wells and watering equipment. With a group, young farmers can work together to deal with agricultural entrepreneurship problems in sand fields. By working together, farmers can produce more efficiently and deal with intermediary traders and market more strongly. This finding is similar to that of $[3,26,8]$.

Meanwhile, young farmers are hesitant about meeting growth needs (3.58), including self-esteem, motivation, and self-actualization. This result implies that they are trying to meet basic and cooperation needs with all their limitations. It is possible to improve growth motivation through group institutions by networking among farmer groups in advocating prices. Young farmers can develop this self-actualization ability through groups.

\subsection{Relationship between Groups' Roles and Young Farmers' Entrepreneurial Motivation}

Table 4 indicates a relationship between motivation and the roles of groups. The results of a significant correlation $(\mathrm{p} \leq 0.05)$ convey a significant relationship between motivation and the role of groups as a vehicle for learning. Groups as a vehicle for learning can increase the group members' adoption and innovation to affect motivation and quality[27], [28]. Meanwhile, the relationship between the groups' roles as a vehicle for collaboration ( $\mathrm{rs}=$ $0.106)$ and building networks ( $\mathrm{rs}=0.041)$ is insignificant.

Table 4. Relationship between Groups' Roles and Young Farmers' Entrepreneurial Motivation

\begin{tabular}{|l|l|}
\hline \multicolumn{1}{|c|}{ Correlates Variables } & \multicolumn{1}{c|}{ rs } \\
\hline Motivation with the role of groups as a learning vehicle & $0.25 * *$ \\
\hline Motivation with the role of groups as a vehicle for cooperation & 0.106 \\
\hline Motivation with the role of groups as a vehicle to build networks & 0.041 \\
\hline
\end{tabular}

Note: * Significant at 0.05 (2-tailed); ** Significant at 0.01 (2-tailed). *P $\leq 0.05$ 
Groups' role as a vehicle for learning is proven to have a high correlation with motivation. This result is similar to [29]. Hence, learning in groups is very useful, meaning forming entrepreneurial motivation among the group members. Therefore, to increase the motivation among young chili farmers, the group needs to optimize its roles in teaching them the necessary skills to develop their entrepreneurial ability.

Farmers learn and discuss among group members; in addition to that, they also invite extension workers and experts, for example, NGOs and academicians. The outside stakeholders provide agricultural knowledge and technical practice; they usually provide capital assistance and equipment. Farmers' improvement ability can indirectly increase their income through improved farming systems and agricultural entrepreneurship. They utilize useful information to advance their business. This study's results are in line with [20], showing that entrepreneurship motivation and increased income correlate positively with farmer groups as a vehicle for learning.

The group's role as a vehicle for collaboration and networking does not affect motivation. It is because farmer groups have not owned many networks with outsiders. Farmer groups in the coastal sand field areas function as learning facilities. Groups are one factor that can increase the young farmers' motivation in farming, primarily through well-organized learning in groups. Growth can be achieved as long as they have good management and provide tangible benefits for young farmers. The auction market is relatively easy for farmers to obtain better prices.

\section{Conclusions and Recommendations}

The groups play a role in increasing young farmers' motivation. Motivation has a strong relationship with the learning process in a group. Young farmers learn by exchanging experiences with other farmers. Various tools, such as discussions, comparative studies, and apprenticeships, are highly beneficial to increase their knowledge and skills. They exchange experiences with other more successful young farmers to increase their motivation. Learning about farming, farming, and innovation skills has become a vehicle for young farmers to learn. Undoubtedly, farming requires skills. The majority of young farmers have a high school education; thus, they can apply innovations. Learning outcomes in groups are expected to improve the quality of farming for young farmers to increase their income.

The highest motivation for young farmers is basic needs (existence), including physical and security needs. This need concerns the fulfillment of food, clothing, and shelter for young farmers and their families. With a vital group role to support and motivate them, young farmers might develop their motivation to engage in horticultural entrepreneurship to develop into successful farmers.

Looking at the importance of farmer groups to motivate young farmers, the government needs to facilitate farmer groups to do better in their roles, primarily as a learning vehicle. Farmers learn in a group by utilizing information technology, inviting experts, and conducting comparative studies. However, other learning methods are required to help farmers increase their knowledge. Through farmer groups, young farmers will gain information about technological innovation and information technology. They can also visit other successful groups to learn from their experience and strengthen the role of extension workers and experts by regularly utilizing young farmer group meetings. They should increase their motivation to be successful young farmers in coastal sandy land through farmer groups. 


\section{References}

1. A. Alomran, Taylor Fr. 18, 171 (2010).

2. D. Ruslanjari and T. Alam, J. Kawistara 7, 115 (2018).

3. A. B. Raya, Asian Soc. Sci. 10, 1 (2014).

4. S. Wiyono, Laporan Kajian Regenerasi Petani (2015).

5. A. D. Nugroho, L. R. Waluyati, and Jamhari, J. Ilmu Pemerintah. Dan Sos. Polit. UMA 6, (2018).

6. Santrock, Life Span Development (Perkembangan Masa Hidup) (Airlangga, Jakarta, 2012).

7. Rahmadanih, S. Bulkis, M. Arsyad, A. Amrullah, and N. M. Viantika, in IOP Conf. Ser. Earth Environ. Sci. (2018).

8. S. Nurlaela, S. Samsi Hariadi, and A. Bihrajihant Raya, Humanit. Soc. Sci. Rev. 8, 518 (2020).

9. S. Nurlaela, S. S. Hariadi, and A. B. Raya, Int. J. Psychosoc. Rehabil. 24, 2020 (2020).

10. E. Fischer and M. Qaim, Food Secur. (2012).

11. O. Anwarudin, S. Sumardjo, A. Satria, and A. Fatchiya, Int. J. Innov. Technol. Explor. Eng. 9, 1008 (2019).

12. D. F. Widhiningsih, Int. J. Soc. Ecol. Sustain. Dev. 11, 45 (2020).

13. R. Kanfer and G. Chen, Organ. Behav. Hum. Decis. Process. 136, 6 (2017).

14. V. Barba-sánchez, C. Atienza-sahuquillo, V. B. Sánchez, and C. A. Sahuquillo, 2523, (2012).

15. E. E. Rasmikayati, I. Setiawan, B. R. Saefudin, and B. Rachmad, J. Pemikir. Masy. Ilm. Berwawasan Agribisnis 3, 134 (2017).

16. M. Benjamin, Asian J. Agric. Extension, Econ. Sociol. 22, 1 (2018).

17. Subejo, R. Ineke, M. Kriska, N. Tsaqib, A. Intan, A. Dwi, and P. Mei, J. Ketahanan Nas. 24, 60 (2018).

18. Pusat Data dan Sistem Informasi Pertanian, Statistik Ketenagakerjaan Sektor Pertanian Tahun 2017-2018 (2018).

19. E. Euriga and S. Amanah, Int. J. Sci. Basic Appl. Res. 38, 160 (2018).

20. A. Adong, F. Mwaura, and G. Okoboi, J. Sustain. Dev. 6, (2013).

21. R. Elizabeth and S. Anugrah, Pus. Anal. Sos. Ekon. Dan Kebijak. Pertan. 134-146, (2014).

22. J. Barham, J. Barham, and C. Chitemi, Food Policy 34, 53 (2018).

23. Edoka, M. H. Igbokwe, and P. E. E. M and Adejo, J. Agric. Ext. 18, 68 (2014).

24. B. M. Taylor and M. Van Grieken, J. Rural Stud. (2015).

25. E. L. Deci, A. H. Olafsen, and R. M. Ryan, Annu. Rev. Organ. Psychol. Organ. Behav. (2017).

26. J. Sulaksana, J. Appl. Sci. 11, 2500 (2011).

27. Mwaura, African Crop Sci. J. 22, 917 (2014).

28. A. Ben Yishay and a M. Mobarak, Mimeo (August 2013) (2013).

29. M. Kamil, Y. Shantini, and C. Sukmana, in (Atlantis Press, 2017), pp. 157-159. 